\title{
EVALUASI PENERAPAN SISTEM PERINGATAN DINI BENCANA LONGSOR DI KAMPUNG JATIRADIO, DESA CILILIN, KECAMATAN CILILIN, KABUPATEN BANDUNG BARAT
}

\section{EVALUATION OF THE APPLICATION OF LANDSLIDE EARLY WARNING SYSTEMS IN JATIRADIO, CILILIN VILLAGE, CILILIN DISTRICT, WEST BANDUNG REGENCY}

\author{
Nana Sudiana ${ }^{1}$ \\ ${ }^{1}$ Pusat Teknologi Reduksi Risiko Bencana - Badan Pengkajian dan Penerapan Teknologi, \\ JI. M. H. Thamrin No. 8, Jakarta 10340 \\ email: nana.sudiana@bppt.go.id
}

\begin{abstract}
Landslides or land movements in Indonesia in recent years have increased in intensity and frequency. One of the efforts to reduce the risk of landslides that has been carried out by the Disaster Risk Reduction Technology Center-BPPT is to build a Landslide Early Warning System in Jatiradio Village, Cililin District, West Bandung Regency. In order to uniform the implementation of an early warning system for landslides or land movements in disaster prone areas, the government has established a national standard namely SNI 8235: 2017 on the Early Warning System for Land Movements. The purpose of this study is to evaluate the compliance between the Landslide Early Warning System that has been developed by PTRRB-BPPT with the Indonesian National Standard for the Land Movement Early Warning System (SNI 8235: 2017). Based on the results of data analysis and evaluation, it can be concluded that the implementation of the landslide early warning system in Jatiradio Village, Cililin Village, Cililin District, West Bandung Regency is in accordance with the Indonesian National Standard (SNI 8235: 2017) concerning the land movement early warning system.
\end{abstract}

Keywords: Indonesian national standard, compliance evaluation, landslide, land movement, early warning, Cililin

\begin{abstract}
ABSTRAK
Beberapa tahun terakhir ini bencana longsor atau gerakan tanah di Indonesia semakin meningkat baik intensitas maupun frekuensinya. Salah satu upaya pengurangan risko bencana longsor yang sudah dilakukan oleh Pusat Teknologi Reduksi Risiko BencanaBPPT adalah membangun Sistem dan Teknologi Peringatan Dini Longsor di Kampung Jatiradio, Desa Cililin, Kecamatan Cililin, Kabupaten Bandung Barat. Dalam rangka menyeragamkan penerapan sistem peringatan dini bencana longsor atau gerakan tanah di kawasan rawan bencana, pemerintah telah menetapkan standard nasional yaitu SNI 8235:2017 tentang Sistem Peringatan Dini Gerakan Tanah. Tujuan kajian ini adalah melakukan evaluasi kesesuaian (compliance) antara Sistem dan Teknologi Peringatan Dini Bencana Longsor yang telah dikembangkan PTRRB-BPPT dengan Standard Nasional Indonesia Sistem Peringatan Dini Gerakan Tanah (SNI 8235:2017). Berdasarkan hasil analisis dan evaluasi data dapat disimpulkan bahwa penerapan pilot project sistem peringatan dini longsor di Kampung Jatiradio, Desa Cililin, Kecamatan Cililin, Kabupaten Bandung Barat telah sesuai dengan Standard Nasional Indonesia (SNI 8235: 2017) tentang Sistem Peringatan Dini Gerakan Tanah.
\end{abstract}

Kata kunci: SNI, evaluasi kesesuaian, longsor, gerakan tanah, peringatan dini, Cililin 


\section{PENDAHULUAN}

\subsection{Latar Belakang}

Wilayah Negara Kesatuan Republik Indonesia merupakan daerah rawan bencana. Setidaknya ada 12 ancaman bencana yang dikelompokkan dalam bencana geologi (gempabumi, tsunami, gunungapi, gerakan tanah/tanah longsor), bencana hidrometeorologi (banjir, banjir bandang, kekeringan, cuaca ekstrim, gelombang ekstrim, kebakaran hutan dan lahan), dan bencana antropogenik (epidemi wabah penyakit dan gagal teknologi kecelakaan industri) (BNPB, 2014). Selama periode 2009-2018 kejadian berbagai jenis bencana di Indonesia terus meningkat. Kejadian bencana tersebut telah menyebabkan kerugian yang sangat besar berupa korban jiwa, bangunan rumah, fasilitas umum, dan harta benda lainnya.

Bencana longsor atau gerakan tanah di Indonesia beberapa tahun terakhir ini semakin meningkat baik intensitas maupun frekuensinya. Berdasarkan data rekapitulasi jumlah kejadian dan korban bencana tanah longsor di Indonesia yang dihimpun oleh Badan Nasional Penanggulangan Bencana (BNPB), menunjukkan bahwa pada tahun 2009 sampai dengan 2018, jumlah kejadian longsor di Indonesia adalah sebanyak 4.366 kali dengan korban penduduk meninggal sebanyak 1.761 orang, luka-luka sebanyak 1.556 orang, terdampak dan mengungsi sebanyak 232.678 orang, rumah rusak berat 12.834 buah, rumah rusak sedang 4.718 buah, rumah rusak ringan 16.754 buah (BNPB, 2020).

Upaya penanggulangan bencana longsor dapat dilakukan melalui pembangunan sistem dan teknologi pengurangan risiko bencana melalui monitoring dan deteksi dini, pemetaan cepat, teknologi adaptasi dan mitigasi bencana. Salah satu upaya yang sudah dilakukan oleh Pusat Teknologi Reduksi Risiko Bencana PTRRB-BPPT adalah membangun sistem dan teknologi peringatan dini longsor di Kampung Jatiradio, Desa Cililin, Kecamatan Cililin, Kabupaten Bandung Barat pada tahun 20182019.

Dalam rangka menyeragamkan penerapan sistem peringatan dini bencana longsor atau gerakan tanah di kawasan rawan bencana, pemerintah telah menetapkan standar nasional yaitu SNI 8235:2017 tentang Sistem Peringatan Dini Gerakan Tanah. SNI ini selanjutnya menjadi acuan dalam melakukan penilaian risiko, deteksi, prediksi, interpretasi, dan respon dalam menghadapi bencana gerakan tanah (BSN, 2017).

Untuk mengetahui apakah Sistem dan Teknologi Peringatan Dini Bencana Longsor yang telah dikembangkan PTRRB-BPPT sudah sesuai dengan SNI 8235:2017, maka dilakukan evaluasi terhadap komponen-komponen sistem yang telah diterapkan.

\subsection{Tujuan}

Melakukan penilaian atau evaluasi kesesuaian (compliance) antara Sistem dan Teknologi Peringatan Dini Bencana Longsor yang telah dikembangkan PTRRB-BPPT dengan Standard Nasional Indonesia Sistem Peringatan Dini Gerakan Tanah (SNI 8235:2017).

\section{BAHAN DAN METODE}

Penilaian dan evaluasi teknologi ini mengacu kepada metodologi audit teknologi. Pada dasarnya audit teknologi atau evaluasi dilakukan melalui tahapan proses persiapan atau perencanaan, pengumpulan dan analisis data/informasi, pelaporan (Kelessidis, 2000; Lambrechts et al., 2011). Berdasarkan pada Standard Kompetensi Kerja Khusus Auditor Teknologi tahapan kerjanya meliputi: merencanakan lokasi dan waktu, mengumpulkan data, mengolah data, menganalisis data, mengevaluasi, dan menyimpulkan (BPPT, 2017).

\subsection{Lokasi dan Waktu Studi}

Studi evaluasi dilaksanakan di Kampung Jatiradio, Desa Cililin, Kecamatan Cililin, Kabupaten Bandung Barat. Waktu studi dilaksanakan pada Tahun 2018-2019.

\subsection{Metode Pengumpulan Data}

Data dan informasi yang dikumpulkan adalah data dan informasi terkait dengan komponen dari SNI 8235:2017 (BSN, 2017), yaitu:

(1) Penilaian risiko berupa survei teknis (geomorfologi, geologi, dan geoteknik), kelembagaan, serta sosial-ekonomibudaya- masyarakat rawan bencana.

(2) Sosialisasi ke masyarakat (tentang bencana gerakan tanah dan pengurangan risiko dengan Sistem Peringatan Dini Longsor)

(3) Pembentukan tim siaga bencana (sudah ada tinggal memperkuat)

(4) Pembuatan panduan operasional evakuasi (peta kerentanan longsor, denah jalur evakuasi dan pemasangan rambu arah evakuasi)

(5) Penyusunan prosedur tetap evakuasi

(6) Pemantauan, sistem peringatan dini, dan geladi evakuasi 
(7) Membangun komitmen otoritas lokal dan masyarakat dalam pengoperasian dan pemeliharaan sistem peringatan dini.

Pengumpulan data dilakukan dengan penelusuran data sekunder dari berbagai laporan dan data primer melalui survei kunjungan ke lokasi pemasangan sistem dan teknologi reduksi risiko bencana, serta melakukan wawancara dengan pelaksana kegiatan.

\subsection{Metoda Pengolahan dan Analisis Data}

Pengolahan data yang diperoleh dilakukan dengan cara pengelompokkan berdasarkan komponen-komponen utama dan pendukung sesuai dengan SNI 8235:2017. Data di masingmasing komponen disusun dan dideskripsikan secara jelas dan terukur memenuhi kebutuhan standar yang sudah ditetapkan dalam SNI tersebut.

Metode analisis yang digunakan pada kegiatan ini adalah dengan cara membandingkan setiap data komponen sistem peringatan dini di lokasi kegiatan dengan komponen yang terdapat di dalam SNI 8235:2017 tentang Sistem Peringatan Dini Gerakan Tanah.

\section{HASIL DAN PEMBAHASAN}

Pembangunan sistem peringatan dini bencana longsor di Kampung Jatiradio, Desa Cililin, Kecamatan Cililin, Kabupaten Bandung Barat telah memenuhi komponen-komponen dari Standar Nasional Indonesia (SNI 8235:2017. Uraian dan analisis masing-masing komponen tersebut disampaikan sebagai berikut:

\subsection{Penilaian Risiko}

Penilaian risiko bencana longsor di lokasi kajian dilakukan melalui 2 pendekatan yaitu melalui pemetaan risiko bencana. Menurut Peraturan Kepala Badan Nasional Penanggulangan Bencana No. 2 Tahun 2012 tentang Pedoman Umum Pengkajian Risiko Bencana, risiko bencana adalah potensi kerugian yang ditimbulkan akibat bencana pada suatu wilayah selama kurun waktu tertentu yang dapat berupa kematian, luka, sakit, hilangnya jiwa, hilangnya rasa aman, mengungsi, kerusakan, atau kehilangan harta dan gangguan kegiatan masyarakat. Sedangkan menurut (Nurjanah et al., 2012), risiko bencana adalah gabungan antara kerentanan dan ancaman serta adanya pemicu dari suatu bencana.
Salah satu komponen penting dalam penentuan ancaman bencana longsor adalah melalui pemetaan bawah permukaan di lokasi rawan longsor. Pemetaan bawah permukaan dilakukan menggunakan geolistrik (Electrical Resistivity Imaging), tujuan utamanya untuk mengetahui titik paling rawan untuk bergerak. mampu mendeteksi metode gofisika yang mampu mendeteksi adanya cracks adalah metode resistivitas, dimana dengan metode ini zona yang memiliki kandungan air jenuh dapat dijadikan acuan tentang adanya cracks dalam tanah (Agustin et al., 2017).

Hasil penentuan titik rawan tersebut selain sebagai masukan dalam pemetaan peta ancaman juga dijadikan dasar untuk pemasangan sensor-sensor sistem peringatan dini bencana longsor. Hasil survei dan analisis data menunjukkan bahwa kedalaman bidang rawan longsor berkisar antara 7,5-9 meter. Berdasarkan hasil tersebut direkomendasikan lokasi sensor pressure transducer berada pada koordinat 107,456426 LS dan -6,954397 BT dengan kedalaman sumur sensor $7,5 \mathrm{~m}$. Sensor inclinometer berada pada koordinat 10,456453 LS dan -6,954404 BT dengan kedalaman sumur sensor $9 \mathrm{~m}$. Dan sensor soil moisture berada pada koordinat 107,456464 LS dan -6,954408 BT dengan kedalaman sumur sensor $1 \mathrm{~m}$. Hasil survei dan analisis geolistrik dan rekomendasi lokasi sensor disajikan pada Gambar 1. (BPPT, 2020).

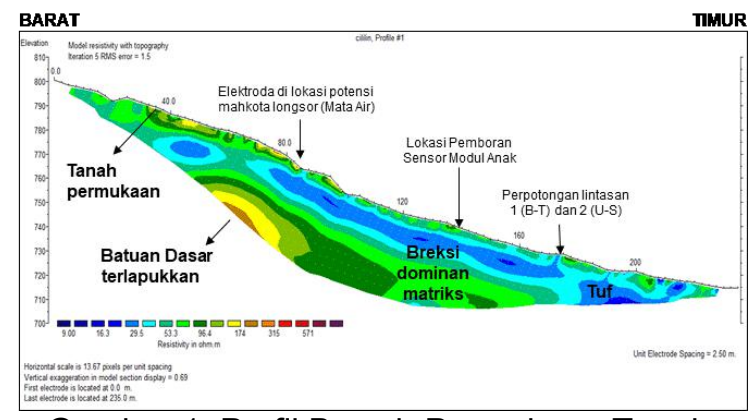

Gambar 1. Profil Bawah Permukaan Tanah

(Sumber: BPPT, 2020).

Kajian analisis risiko bencana dengan melakukan pemetaan risiko bencana belum ada standarisasi yang baku dalam penyusunan peta risiko bencana sehingga setiap lembaga atau institusi memiliki metode yang berbeda (Aminatun, 2017). Namun demikian sebagai dasar pemilihan kelas dan pembobotan pada penilaian ini mengacu pada Perka BNPB No 2 tahun 2012. Untuk meningkatkan akurasi hasil metode penilaian dan pembobotan dilakukan modifikasi sesuai dengan kondisi di lapangan.

Hasil analisis penilaian risiko bencana longsor di 6 Sub DAS di lokasi kajian didominasi oleh kelas risiko rendah (43\%) 
hingga sedang (53\%). Secara rinci sebaran kelas risiko di lokasi kajian disajikan pada Tabel 1 dan Gambar 1 (BPPT, 2020).

Tabel 1. Luasan Kelas Risiko di Sub-DAS Cililin

\begin{tabular}{l|r|c}
\hline \multicolumn{1}{c|}{ Kelas Risiko } & Luas (Ha) & $\begin{array}{c}\text { Prosentase } \\
(\%)\end{array}$ \\
\hline Rendah & 24,22 & 43 \\
\hline Sedang & 29,77 & 53 \\
\hline TInggi & 2,54 & 4 \\
\hline Total & 55,43 & 100 \\
\hline
\end{tabular}

Sumber: BPPT, 2020

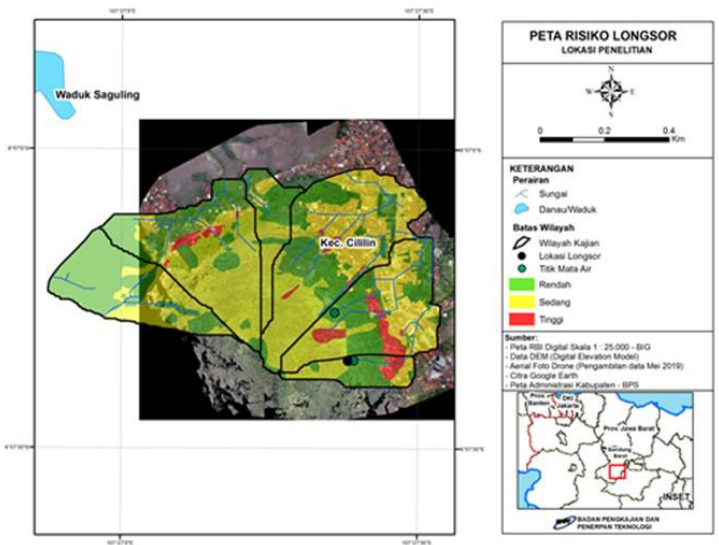

Gambar 2. Peta Risiko Bencana Longsor (Sumber: BPPT, 2020)

Berdasarkan uraian di atas, maka komponen pertama penilaian risiko pada kegiatan penerapan sistem teknologi peringatan dini bencana longsor di Kampung Jatiradio, Desa Cililin, Kecamatan Cililin, Kabupaten Bandung Barat telah terlaksana.

\subsection{Sosialisasi}

Sosialisasi penerapan sistem dan teknologi peringatan dini bencana longsor kepada masyarakat di lokasi telah dilaksanakan dengan baik. Tujuan sosialisasi ini adalah untuk memberikan pemahaman kepada masyarakat tentang potensi bahaya bencana longsor dan sistem teknologi peringatan dini bencana longsor. Peningkatan pengetahuan untuk sadar terhadap kesiapsiagaan bencana dapat dilakukan dengan sosialisasi dengan tujuan untuk mengurangi risiko korban saat terjadi bencana (Pahleviannur, 2019). Program sosialisasi pengurangan risiko bencana termasuk salah satu dari sekian banyak program pemerintah yang menyangkut kepentingan rakyat. Sosialisasi merupakan salah satu aktivitas komunikasi karena di dalam sosialisasi terjadi proses komunikasi. Komunikasi adalah proses penyampaian pesan dari komunikator kepada komunikan melalui media untuk mendapatkan respon, (Laswell,
1948 dalam Arimastuti, 2011). Untuk menurunkan resiko bencana, tentu memerlukan suatu strategi komunikasi yang efektif agar kegiatan penurunan risiko bencana dapat berjalan secara optimal (Prasanti dan Fuady, 2017).

Peserta yang hadir pada acara sosialisasi mencakup berbagai pihak yaitu Kepala Desa Cililin, Ketua Badan Pemberdayaan Desa (BPD) Cililin, Ketua Kelompok Siaga Bencana (KSB) Desa Cililin, Ketua Karang Taruna Desa Cililin, Kepala Puskesman Cililin, Ketua RW $(1,2,3,4,7,12)$, Perhutani-Bagian Kesatuan Pemangkuan Hutan (BKPH) Cililin, Palang Merah Indonesia Kabupaten Bandung Barat, dan perwakilan masyarakat Kampung Jatiradio.

Sesuai dengan tujuan kegiatan sosialisasi, materi yang telah disampaikan meliputi gambaran potensi bahaya longsor di lokasi kajian dan sistem peringatan dini bencana longsor. Potensi bahaya longsor digambarkan dalam bentuk Peta Bahaya Longsor yang telah disusun berdasarkan kajian yang telah dilakukan pada tahun 2018, dan Sistem Peringatan Dini Bencana Longsor berupa pilot project yang telah dipasang pada tahun 20182019 (BPPT, 2020). Kegiatan sosialisasi disajikan pada Gambar 3.

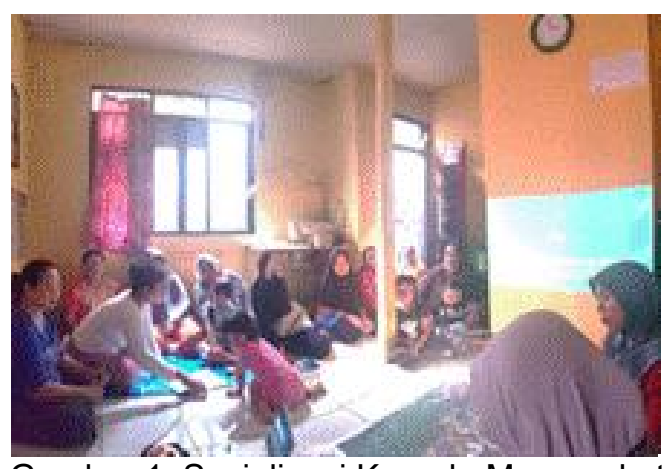

Gambar 1. Sosialisasi Kepada Masyarakat (Sumber: BPPT, 2020)

\subsection{Tim Siaga Bencana}

Pemerintah tidak akan mampu melakukan manajemen risiko bencana secara optimal tanpa melibatkan masyarakat secara aktif. Keterlibatan masyarakat dalam manajemen risiko bencana mutlak diperlukan karena masyarakat adalah subjek sekaligus objek dari manajemen risiko bencana (Susilowati dan Siswanta, 2016). Keterlibatan aktif masyarakat tersebut diwujudkan dalam bentuk tim siaga bencana.

Tim siaga bencana di tingkat Desa Cililin telah dibentuk oleh BPBD dan Dinas Sosial yang ditetapkan oleh Bupati Kabupaten Bandung Barat dengan nama Kelompok Siaga 
Bencana (KSB) Desa Cililin. Struktur KSB terdiri dari Penasihat, Pembina, Ketua, Sekretaris, Bendahara, Tim Logistik, Tim keamanan, Tim Evakuasi, dan Tim Dapur. Total personil yang sudah dilantik sebanyak 40 orang. Tim KSB tersebut sudah sesuai dengan arahan struktur orgnisasinya SNI (Gambar 4).

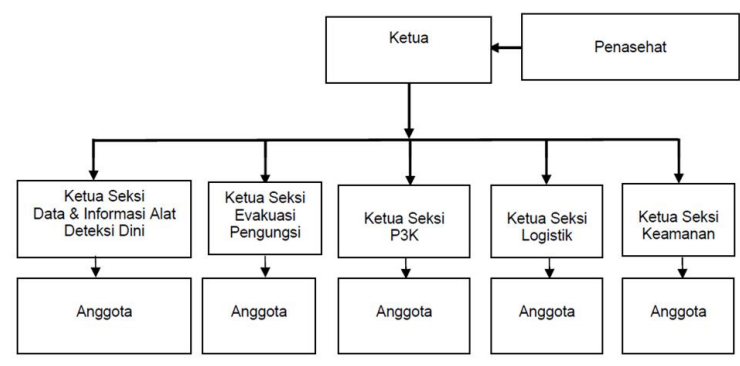

Gambar 2. Struktur Organisasi Tim Siaga Bencana Longsor di Desa Cililin

\subsection{Pembuatan Panduan Operasional Evakuasi}

Panduan operasional evakuasi terdiri dari peta kerentanan, denah jalur evakuasi, dan pemasangan rambu-rambu arah evakuasi. Ketiga aspek tersebut telah dilaksanakan di lokasi kajian. Dalam menetapkan dan menyiapkan jalur evakuasi, perlu memperhatikan beberapa hal penting sebagai berikut (Supartini et al., 2017):

1. Jalur evakuasi yang merupakan rute tercepat dan teraman bagi pengungsi menunju tempat pengungsian.

2. Rute alternatif selain rute utama.

3. Kesesuaian waktu yang dibutuhkan untuk mencapai tempat pengungsian.

4. Kelengkapan sumber daya termasuk ketersediaan kendaraan yang dapat digunakan dalam proses evakuasi.

5. Peta evakuasi berdasarkan hasil survei dan desain yang menginformasikan jalur evakuasi, tempat pengungsian dan waktu untuk mencapainya, jalur alternatif, lokasilokasi aman bencana, serta posisi posko siaga tim evakuasi.

Bersarkan Peraturan Kepala BNPB No.2 Tahun 2012 tentang Pedoman Umum Pengkajian Risiko Bencana menyebutkan bahwa peta kerentanan terdiri dari penilaian kerentanan sosial, ekonomi, fisik, dan lingkungan. Pada penilaian tersebut setiap Parameter memiliki bobot yaitu Sosial $40 \%$, Ekonomi 25\%, Fisik 25\%, dan Lingkungan 10\%.

Pedoman umum pengkajian risiko bencana BNPB merupakan pedoman yang diperuntukkan untuk penilaian skala Provinsi/Kabupaten/Kota. Dalam kegiatan kajian ini, wilayah yang dikaji adalah skala desa sehingga diperlukan penyesuaian pedoman dalam penilaian kerentanan. Oleh karena itu, pedoman umum BNPB ini kemudian didiskusikan dengan para ahli untuk mendapatkan justifikasi para ahli dalam memodifikasi pedoman penilaian.

Pedoman penilaian yang telah dimodifikasi tetap mencakup empat parameter, yaitu sosial $40 \%$, ekonomi $25 \%$, fisik $25 \%$, dan lingkungan $10 \%$. Akan tetapi indikator penilaian dalam parameter tersebut disesuaikan dengan kondisi wilayah kajian. Hasil analisis spasial diperoleh peta kerentanan bencana longsor di Kampung Jatiradio, Desa Cililin, Kecamatan Cililin, Kabupaten Bandung Barat disajikan pada Tabel 2 dan Gambar 5.

Tabel 2. Luas Kerentanan Pada Daerah Penelitian

\begin{tabular}{l|r|c}
\hline $\begin{array}{c}\text { Kelas } \\
\text { Kerentanan }\end{array}$ & \multicolumn{1}{|c}{ Luas (Ha) } & $\begin{array}{c}\text { Prosentasi } \\
(\%)\end{array}$ \\
\hline Rendah & 23,351 & 42,46 \\
\hline Sedang & 1,840 & 3,35 \\
\hline Tinggi & 29,802 & 54,19 \\
\hline Total Luas & 54,993 & 100,00 \\
\hline
\end{tabular}

Sumber: BPPT, 2020

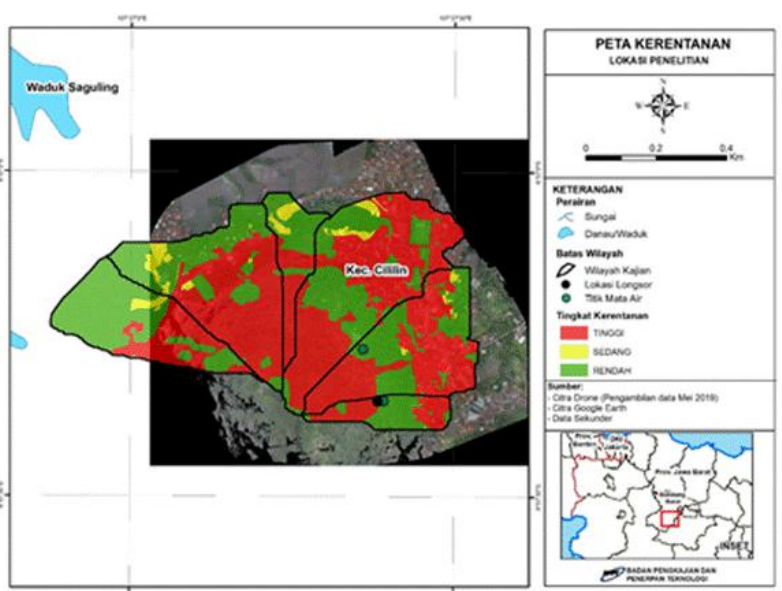

Gambar 3. Peta Kerentanan Longsor

(Sumber: BPPT, 2020)

Pembuatan denah evakuasi mengacu pada Undang-Undang No. 28 tahun 2002 tentang Bangunan Gedung, dimana didalamnya tercantum kriteria ataupun syarat jalur evakuasi.

1. Memiliki akses langsung ke jalan atau ruang terbuka yang aman, dilengkapi penanda yang jelas dan mudah terlihat.

2. Dilengkapi penerangan yang cukup.

3. Bebas dari benda yang mudah terbakar atau benda yang dapat membahayakan.

Dari hasil survei yang telah dilakukan dapat diketahui bahwa kampung Jatiradio memiliki beberapa jalan kecil yang tidak termasuk dalam kriteria jalan evakuasi. Beberapa jalan kecil dengan lebar hanya $30-40 \mathrm{~cm}$ tidak akan dilalui 
untuk jalur evakuasi (tanda silang merah pada Gambar 6).

Pada Zona A, masyarakat yang tinggal disekitarnya bisa berjalan ke arah selatan langsung menuju jalan raya Cililin-Cihampelas apabila sirene sensor tanda bahaya berbunyi. Masyarakat yang berada di wilayah tersebut bisa menuju titik kumpul sementara dengan berjalan kaki dengan waktu tempuh paling cepat kira-kira 4-6 menit.

Sedangkan pada zona B, masyarakat bisa langsung menuju jalan utama di sebelah masjid dan pangkalan ojek kemudian belok ke kanan menuju titik kumpul sementara yang berada di depan Puskesmas Dengan Tempat Perawatan (DPT) Cililin. Jarak tempuh paling cepat zona B menuju titik kumpul sementara yaitu 1-5 menit. Masyarakat di sekitar zona B sudah memiliki kesadaran akan bahaya longsor dan langsung mengungsi ketika hujan dengan intensitas besar selama 4 jam lebih.

Pada zona C waktu tempuh yang dibutuhkan untuk menuju titik kumpul sementara cukup lama karena jalan kecil yang berliku yang harus dilalui dan cenderung licin saat hujan sehingga tidak bisa berjalan dengan cepat. Untuk zona ini, waktu tempuh perkiraan menuju titik kumpul adalah 4-7 menit. Pembagian zona jalur evakuasi longsor disajikan pada Gambar 6.

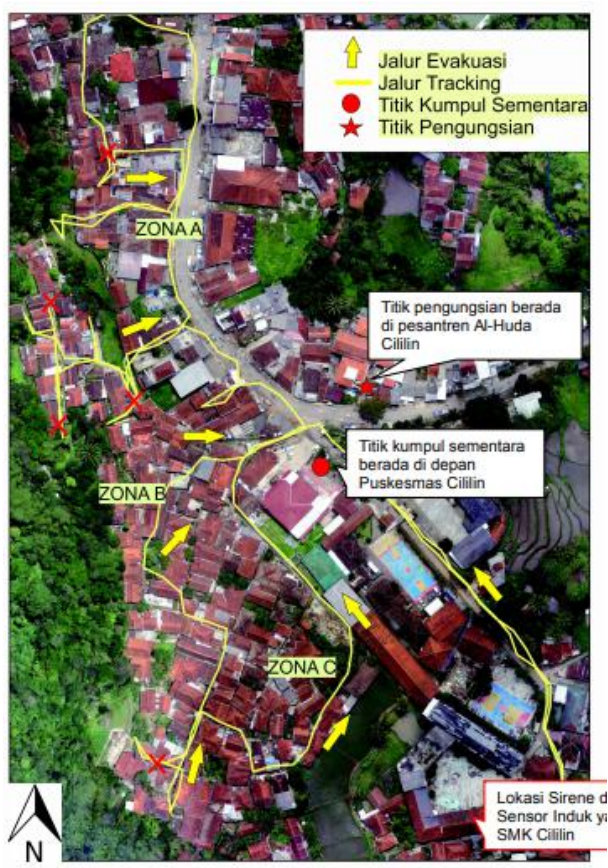

Gambar 4. Pembagian Zona Evakuasi Longsor (Sumber: BPPT, 2020)

Denah jalur evakuasi dibuat dengan mempertimbangkan analisis aksesibilitas jalur dan rute tercepat. Sebelumnya telah dilakukan survei jalur di lapangan. Hasil dari survei jalur ini kemudian dimasukan dalam software pemetaan berupa line jalur hasil tracking dalam bentuk shapefile. Jalur tersebut kemudian dibuat ulang dengan memotong line jalur pada setiap persimpangan jalan. Setelah itu dilakukan Network Analysis dengan software pemetaan sehingga dapat diketahui fastest route dari sebuah titik menuju titik Kumpul / titik evakuasi sementara (Gambar 7).

Dari hasil Network Analysis dan Analisis Aksesibilitas Jalur, didapatkan titik-titik yang memerlukan rambu evakuasi/petunjuk arah menuju titik kumpul untuk mempermudah masyarakat melakukan evakuasi. Rambu yang dibutuhkan dalam jalur evakuasi ini ada delapan rambu dengan keterangan:

- Rambu petunjuk belok kanan 3 buah

- Rambu petunjuk belok kiri 3 buah

- Rambu petunjuk lurus 1 buah

- Rambu titik kumpul 1 buah

Rambu diletakkan pada titik dimana terdapat persimpangan arah ataupun titik yang jalannya belum terlalu jelas. Proses pemasangan rambu disajikan pada Gambar 8 (BPPT, 2020).

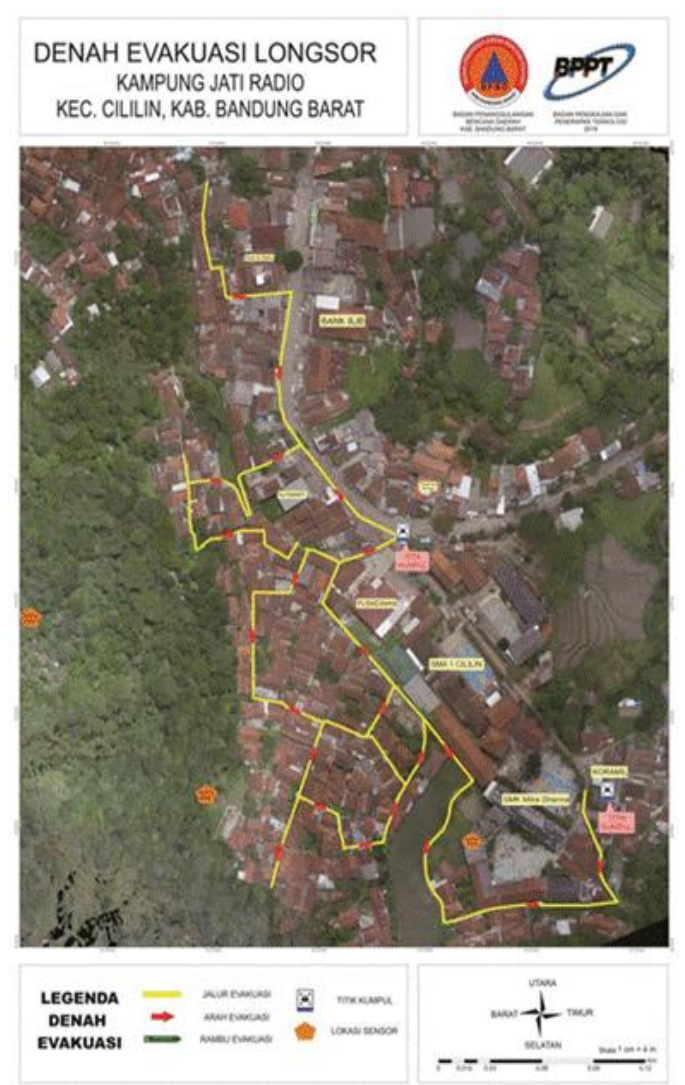

Gambar 5. Jalur Evakuasi Longsor (Sumber: BPPT, 2020) 


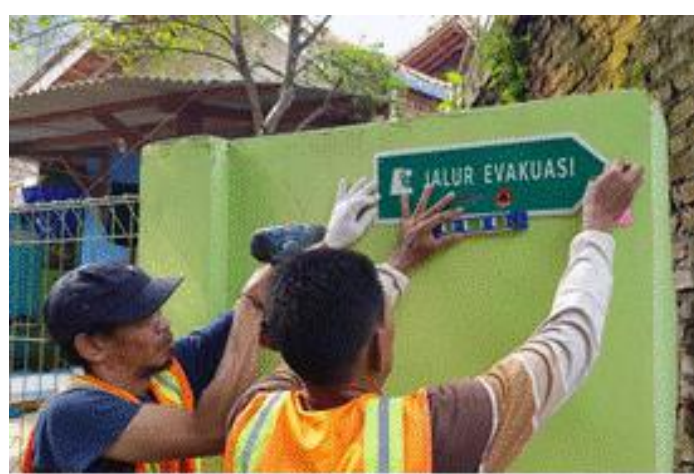

Gambar 6. Pemasangan Rambu Evakuasi Longsor (Sumber: BPPT, 2020)

\subsection{Penyusunan Prosedur Tetap Evakuasi}

Prosedur tetap evakuasi adalah pedoman bagi masyarakat untuk melakukan evakuasi pada saat terjadi ancaman longsor. Dengan adanya prosedur tetap ini diharapkan masyarakat memiliki pengetahuan dan pemahaman yang sama terhadap proses evakuasi, sehingga proses evakuasi dapat berjalan tertib dan aman.

Prosedur tetap evakuasi longsor disusun dan ditetapkan oleh tim pengembangan sistem peringatan dini dan dikonsultasikan ke masyarakat untuk mendapatkan masukan dan koreksi sesuai dengan kondisi di lapangan. Status tingkat bahaya dibagi menjadi 3 (tiga) klasifikasi yaitu Waspada (Tingkat 1), Siaga (Tingkat 2) dan Awas (Tingkat 3). Uraian masing-masing tingkatan tersebut sebagai berikut (BPPT, 2020):

\section{Waspada (Tingkat 1)}

a. Kriteria/Tanda

Kriterianya ditentukan oleh pengukuran curah hujan atau pencatatan getaran. Tandanya berupa lampu dengan warna "biru" dan atau sirene dengan bunyi "waspada, curah hujan tinggi" atau tanda bunyi lainnya yang menunjukkan tingkat ancaman terendah atau tingkat waspada atau disesuaikan dengan kondisi setempat.

\section{b. Tindakan/respon masyarakat}

- Ketua tim melakukan koordinasi dengan tim siaga bencana.

- Seksi data dan informasi mengecek kondisi alat pemantau dan mendata warga, serta menyampaikan informasi tingkat ancaman dan meminta untuk mempersiapkan barangbarang penting yang perlu dibawa.

- Tim siaga bencana memberi laporan berkala kepada ketua tim. c. Tindakan otoritas lokal

- Menerima laporan dari ketua tim siaga bencana.

- Memeriksa kondisi lapangan dan tetap berkoordinasi dengan tim siaga bencana.

\section{Siaga (Tingkat 2)}

a. Kriteria/Tanda

Kriteria ditentukan oleh peningkatan curah hujan atau hidrologi lereng, peningkatan getaran, dan indikasi pergerakan tanah. Tanda lampu berwarna "oranye" dan bunyi sirene "siaga, evakuasi" atau tanda bunyi lainnya yang menunjukkan tingkat ancaman meningkat menjadi tingkat siaga atau disesuaikan dengan kondisi setempat.

b. Tindakan/respon masyarakat

- Ketua tim melakukan koordinasi dengan tim siaga bencana.

- Seksi data dan informasi kembali mengecek kondisi pergerakan tanah dan alat-alat pemantau, serta melakukan pendataan.

- Ketua tim memberi perintah evakuasi kepada kelompok rentan menuju titik kumpul dibantu seksi mobilisasi pengungsi dan seksi keamanan.

- Seksi data melakukan pendataan kelompok rentan guna memastikan seluruh kelompok rentan telah dievakuasi.

- Seksi keamanan bertugas memastikan keamanan rumah warga dan lingkungan

c. Tindakan otoritas lokal

- Menerima laporan dari ketua tim siaga bencana.

- Memeriksa kondisi lapangan dan berkoordinasi dengan tim siaga bencana.

- Memberikan bantuan terhadap kelompok rentan yang telah dievakuasi

\section{Awas (Tingkat 3)}

a. Kriteria/Tanda

Kriteria ditentukan oleh peningkatan curah hujan atau hidrologi lereng, peningkatan percepatan pergerakan, dan peningkatan percepatan gerakan tanah.

Tandanya lampu berwarna "merah" dan sirene dengan bunyi "evakuasi" atau tanda bunyi lainnya yang menunjukkan tingkat ancaman tertinggi atau tingkat awas atau disesuaikan dengan kondisi setempat. 
b. Tindakan/respon masyarakat

- Ketua tim melakukan koordinasi seluruh tim siaga bencana.

- Ketua tim memberi perintah evakuasi kepada seluruh warga menuju titik kumpul dibantu seksi mobilisasi pengungsi dan seksi keamanan.

- Seksi data dan informasi mengecek peralatan deteksi dini dan melakukan pendataan warga di tempat pengungsian.

c. Tindakan otoritas lokal

- Menerima laporan dari ketua tim siaga bencana.

- Memeriksa kondisi lapangan dan berkoordinasi dengan tim siaga bencana.

- Memberikan bantuan tanggap darurat terhadap seluruh masyarakat yang telah dievakuasi.

\subsection{Pemantauan, Sistem Peringatan Dini dan Geladi Evakuasi}

Peringatan dini merupakan faktor utama dalam pengurangan risiko bencana. Peringatan dini dapat mencegah korban jiwa dan mengurangi dampak ekonomi dan material dari sebuah bencana. Agar berjalan efektif, sistem peringatan dini harus melibatkan masyarakat secara aktif, memfasilitasi pendidikan dan kesadaran masyarakat tentang risiko yang dihadapi, menyebarluaskan pesan dan peringatan secara efektif, serta menjamin kesiapsiagaan yang selalu terjaga (UN/ISDR, 2006). Sistem peringatan dini yang lengkap dan efektif terdiri atas empat unsur yang saling terkait, yaitu pengetahuan tentang risiko, pemantauan dan layanan peringatan, penyebarluasan dan komunikasi, dan kemampuan penanggulangan. Layanan peringatan merupakan inti dari sistem. Harus ada dasar ilmiah yang kuat untuk dapat memprediksi dan meramalkan munculnya bahaya, dan harus ada sistem peramalan dan peringatan yang andal yang beroperasi 24 jam sehari (BNPB, 2012).

Pemantauan dan sistem peringatan dini longsor sudah dilakukan melalui pemasangan Pilot Project sistem peringatan dini longsor (Landslide Early Warning System-LEWS). Sistem peringatan dini longsor ini memiliki 2 komponen penting yaitu modul induk dan modul anak. Modul induk berfungsi sebagai pengelola dan pengendali data utama yang terdiri dari unit data logger atau micro controller, unit sistem audio, unit sumber daya listrik dengan pengisian oleh panel surya, dan sistem penakar air hujan. Modul anak fungsi utamanya adalah akuisisi data dari sensor dan analisis data tersebut dengan nilai ambang batas peringatan dini longsor (threshold). Modul anak terdiri dari unit micro controller, dan 4 unit sensor yaitu accelerometer, inclinometer, soil moisture, dan water pressure transducers. LEWS ini bekerja secara otomatis, yaitu mulai dari akuisisi data dari sensor, analisis data, pengiriman data ke modul induk, jika data melebihi ambang batas maka induk memberi peringatan dini melalui pengeras suara, semua data kemudian dikirim secara periodik ke server melalui modem GSM sebagai data series pemantauan di lokasi rawan longsor.

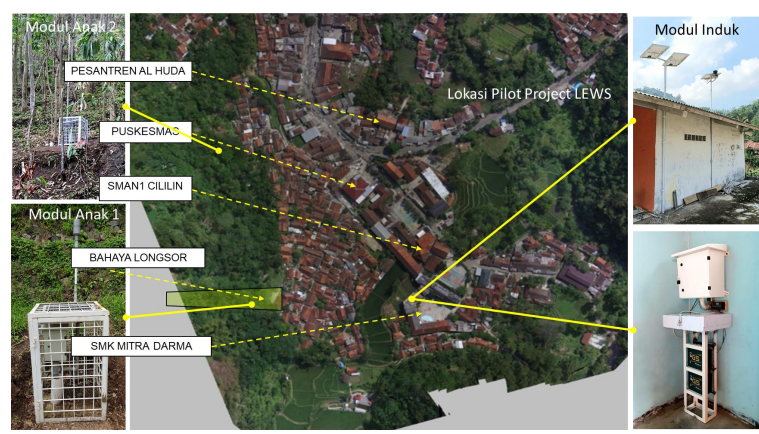

Gambar 7. Pilot Project Sistem Peringatan Dini Longsor (Sumber: BPPT, 2020).

Sistem peringatan dini longsor yang sudah dipasang tersebut beberapa komponen sudah memenuhi komponen wajib dan tambahan yang diuraikan di dalam SNI 8235:2017, yaitu:

1. Alat penakar hujan

2. Alat pengukur deformasi permukaan tanah, yaitu untuk mengukur deformasi di atas permukaan tanah dalam kurun waktu tertentu. Alat yang umum digunakan yaitu pemantau perubahan jarak relatif antar dua titik pada rekahan (accelerometer) dan alat pengukur perubahan kemiringan permukaan tanah (tiltmeter).

3. Alat pengukur deformasi bawah permukaan (inclinometer)

4. Alat pengukur fluktuasi muka air tanah (ground water level measurement meter).

5. Alat pengukur kadar air tanah (soil moisture measurement).

\subsection{Membangun Komitmen Otoritas Lokal dan Masyarakat dalam Pengoperasian dan Pemeliharaan Sistem Peringatan Dini Longsor}

Pengurangan risiko bencana mensyaratkan bahwa tanggung jawab dibagi oleh pemerintah pusat dan otoritas nasional yang relevan, sektor dan pemangku kepentingan, yang sesuai dengan keadaan nasional mereka dan sistem pemerintahan. Pengurangan risiko bencana membutuhkan keterlibatan dan kemitraan 
semua lapisan masyarakat. Juga membutuhkan pemberdayaan dan partisipasi inklusif, mudah diakses, dan non diskriminatif, memberikan perhatian khusus kepada orang-orang yang secara tidak proporsional terkena dampak bencana, terutama yang paling miskin. (UN/ISDR, 2015).

Komitmen otoritas lokal dan masyarakat secara prinsip sudah disepakati melalui rancangan perjanjian kerja sama antara BPPT dan BPBD Kabupaten Bandung Barat. Pada pasal 4 disebutkan Hak dan Kewajiban dari masing-masing pihak sesuai dengan tugas pokok dan fungsinya. Pihak pertama BPPT memiliki hak dan kewajiban:

1. Membangun sistem peringatan dini longsor di Kampung Jatiradio, Desa Cililin, Kecamantan Cililin, Kabupaten Bandung Barat.

2. Melakukan pemantauan kinerja sistem peringatan dini longsor.

3. Melakukan sosialisasi kepada pemangku kepentingan dan masyarakat.

4. Melakukan geladi kesiapsiagaan masyarakat.

5. Menyerahkan asset sistem peringatan dini kepada BPBD Kabupaten Bandung Barat.

6. Melakukan transfer teknologi dan pengetahuan operasional dan perawatan sistem peringatan dini longsor.

7. Menyediaan tenaga ahli pada saat operasional dan pemeliharaan.

Hak dan Kewajiban pihak kedua BPBD Kabupaten Bandung Barat adalah:

1. Melakukan pendampingan selama pembangunan sistem peringatan dini longsor.

2. Mendapatkan akses untuk melakukan pemantauan kinerja sistem peringaan dini.

3. Melakukan pendampingan dalam sosialisasi kepada pemangku kepentingan dan masyarakat.

4. Melakukan pendampingan dalam geladi kesiapsiagaan masyarakat.

5. Menerima penyerahan aset sistem peringatan dini longsor.

6. Menyediakan sumberdaya manusia dan anggaran untuk operasionalisasi dan perawatan.

Berdasarkan uraian ketujuh komponen SNI 8235:2017 tersebut, dapat dinyatakan bahwa kegiatan penerapan teknologi sistem peringatan dini longsor di Desa Cililin, Kecamatan Cililin, Kabupaten Bandung Barat telah sesuai atau memenuhi arahan dari SNI 8235:2017 tentang Sistem Peringatan DIni Gerakan Tanah.

\section{KESIMPULAN}

Berdasarkan hasil analisis data dan pembahasan di atas, disimpulkan bahwa penerapan pilot project sistem peringatan dini longsor di Kampung Jatiradio, Desa Cililin, Kecamatan Cililin, Kabupaten Bandung Barat telah sesuai dengan Standar Nasional Indonesia (SNI 8235: 2017) tentang Sistem Peringatan Dini Gerakan Tanah. Komponen SNI 8235:2017 tersebut:

(1) Penilaian risiko berupa penyusunan peta bahaya, peta kerentanan, dan peta risiko serta survei geolistrik menentukan batas bidang gelincir longsor.

(2) Sosialisasi ke masyarakat (tentang bencana gerakan tanah dan pengurangan risiko dengan sistem peringatan dini longsor).

(3) Pembentukan tim siaga bencana yaitu Kelompok Siaga Bencana (KSB) Desa Cililin.

(4) Pembuatan panduan operasional evakuasi yaitu peta kerentanan longsor, denah jalur evakuasi, dan pemasangan rambu arah evakuasi.

(5) Penyusunan prosedur tetap evakuasi yaitu Waspada, Siaga, dan Awas.

(6) Pemantauan, sistem peringatan dini, dan geladi evakuasi yaitu pemasangan pilot project sistem peringatan dini longsor dan pelaksanaan geladi kesiapsiagaan masyarakat terhadap bahaya longsor.

(7) Membangun komitmen otoritas lokal dan masyarakat dalam pengoperasian dan pemeliharaan sistem peringatan dini yaitu perjanjian kerjasama antara BPPT dengan BPBD Kabupaten Bandung Barat.

\section{DAFTAR PUSTAKA}

Agustin A.D., W. Utama dan J.P.G.N. Rochman. 2017. Identifikasi Letak Cracks pada Bidang Longsor Menggunakan Metode Resistivitas 2D. JURNAL TEKNIK ITS. 6(1): C-103-C-105.

Aminatun S. 2017. Kajian Analisis Risiko Bencana Tanah Longsor Sebagai Dasar Dalam Pembangunan Infrastruktur Di Desa Sriharjo Kecamatan Imogiri Kabupaten Bantul. Jurnal Teknisia. XXII(2): 372-382.

Arimastuti, A. 2011. Tahapan Proses Komunikasi Fasilitator Dalamsosialisasi Pengurangan Risiko Bencana (Studi Kasus terhadap Tim COMPRESS LIPI dalam Pelatihan Evakuasi Mandiri bagi Masyarakat Pantai terhadap Bahaya Tsunami (Pra Tsunami)). Jurnal Penanggulangan Bencana. 2(2): 15-23. 
Badan Nasional Penanggulangan Bencana. 2012. Pedoman Sistem Peringatan Dini Berbasis Masyarakat. Jakarta.

Badan Nasional Penanggulangan Bencana. $2014 . \quad$ Rencana Nasional Penanggulangan Bencana 22015-2019. Jakarta.

Badan Nasional Penganggulangan Bencana. 2020. Data Informasi Bencana Indonesia (DIBI) [terhubung berkala]. http:// dibi.bnpb.go.id/DesInventar/main.jsp [17 Januari 2019].

Badan Standardisasi Nasional. 2017. Standar Nasional Indonesia Nomor 8235:2017 Sistem Peringatan Dini Gerakan Tanah. Jakarta.

Badan Pengkajian dan Penerapan Teknologi. 2017. Peraturan Kepala Badan Pengkajian dan Penerapan Teknologi Nomor 007a Tahun 2017 Tentang Pelaksanaan Audit Teknologi. Jakarta.

Kelessidis V. 2000. Technology Audit. INNEREGIO: dissemination of innovation and knowledge management techniques. Thessaloniki Technology Park. Yunani.

Lambrechts A.J, J.E. Lourens, P.B. Millar, D.E. Sparks. 2011. Global Technology Audit Guide (GTAG®) 16 Data Analysis Technologies. The Institute of Internal Auditors located at 247 Maitland Avenue, Altamonte Springs, FL 32701, USA.

Nurjanah, D., D. Kuswanda, dan A. Siswanto. 2012. Manajemen Bencana. Badung: Alfabeta.

Pahleviannur, M.R. 2019. Edukasi Sadar Bencana Melalui Sosialisasi

Kebencanaan Sebagai Upaya Peningkatan Pengetahuan Siswa Terhadap Mitigasi Bencana. Jurnal Pendidikan IImu Sosial. 29(1): 49-55.

Prasanti D. dan I. Fuady. 2017. Strategi Komunikasi Dalam Kesiapan Menghadapi Bencana Longsor Bagi Masyarakat Di Bandung Barat (Studi Kasus Tentang Strategi Komunikasi Dalam Kesiapan Menghadapi Bencana Longsor Bagi Masyarakat Kawasan Pertanian Di Kaki Gunung Burangrang, Kab.Bandung Barat). Komunikasi. XI(2): 135-148.

Pusat Teknologi Reduksi Risiko Bencana-BPPT. 2020. Laporan Akhir Kegiatan Pengkajian dan Penerapan Teknologi Reduksi Risiko Bencana Longsor Tahun 2019. Jakarta.

Susilowati F. dan L. Siswanta. 2016. Peningkatan Kapasitas Masyarakat Dalam Menghadapi Risiko Bencana Berbasis Gender. Jurnal SEMAR. 5(1): 41-49.
Supartini E., N. Kumalasari, D. Andry, Susilastuti, I. Fitrianasari, J. Tarigan, A.A. HAryanta, dan R Nugi. 2017. Buku Pedoman Latihan Kesiapsiagaan Bencana-Membangun Kesadaran, Kewaspadaan dan Kesiapsiagaan Dalam Menghadapi Bencana. Badan Nasional Penanggulangan Bencana. Jakarta.

UN Secretariat of the International Strategy for Disaster Reduction (UN/ISDR). 2006. Membangun Sistem Peringatan Dini: Sebuah Daftar Periksa. Konferensi Internasional Ketiga tentang Peringatan Dini 27-29 Maret 2006. Bonn, Jerman.

UN Secretariat of the International Strategy for Disaster Reduction (UN/ISDR). 2015. Kerangka Kerja Sendai untuk pengurangan Risiko BencanaTahun 2015-2030. [terhubung berkala]. 